\title{
Hubungan Self Efficacy dan Self Esteem Dengan Perilaku Berisiko Remaja
}

\section{Sri Astutik Andayani ${ }^{1}$, Nahdia Fiki Maghfiroh ${ }^{2}$, Novita Riska Anggraini ${ }^{3}$}

1. Universitas Nurul Jadid, Email: astutikandayani@unuja.ac.id

2. Universitas Nurul Jadid, Email : nahdiafiki432@gmail.com

3. Universitas Nurul Jadid, Email: novitariska06@gmail.com

\section{Abstract}

This study aims to analyze the relationship between self-efficacy and self-esteem, with juvenile delinquency. The population of this study were students of Nurul Jadid University with a sample of 120 aged between 19-21 years. The sampling technique used is simple random sampling. The data collection tool in this study was a Likert scale. This study uses statistical analysis of the Spearman rho correlation. The results show that there is a significant relationship between self-efficacy, selfesteem, and juvenile delinquency. There is a correlation between self-efficacy and juvenile delinquency $(p=0.000)$, there is a correlation between self-esteem and juvenile delinquency $(p=0.000)$. The higher the self-efficacy and self-esteem, the juvenile delinquency tends to be low or not at risk.

Keywords: self efficacy, self esteem, juvenile delinquency 


\section{Abstrak}

Penelitian ini bertujuan menganalisis hubungan antara self efficacy dan self esteem, dengan kenakalan remaja. Populasi penelitian ini adalah mahasiswa Universitas Nurul Jadid dengan sampel sebanyak 120 yang berusia antara 19- 21 tahun. Teknik pengambilan sampel yang digunakan adalah simple random sampling. Alat pengumpul data dalam penelitian ini berupa skala likert. Penelitian ini menggunakan analisis statistik korelasi Spearman rho.Hasil penelitian menunjukkan terdapat hubungan signifikan antara self efficacy, self esteem, dengan kenakalan remaja. Adanya korelasi antara self efficacy dengan kenakalan remaja $(p=0,000)$, adanya korelasi antara self esteem dengan kenakalan remaja ( $p=0,000)$. Semakin tinggi self efficacy dan self esteem maka kenakalan remaja cenderung rendah atau tidak berisiko.

Kata kunci: self efficacy, self esteem, kenakalan remaja 
Sri Astutik Andayani: Self Efficacy 


\section{PENDAHULUAN}

Fenomena

kenakalan remaja juga ditemukan pada remaja di Pondok Pesantren. Kehidupan remaja tidak terlepas dari permasalahan dalam masa pertumbuhan dan perkembangannya.

ada tersebut dapat
bersumber dari berbagai macam faktor baik internal maupun faktor eksternal, seperti dari dalam diri sendiri, keluarga, teman sepergaulan atau lingkungan sosial. Masa remaja dipandang sebagai masa "storm and stress", remaja mengalami pergolakan yang dipenuhi oleh konflik dan perubahan suasana hati. Berbagai pikiran, perasaan, dan tindakan remaja berubah- rubah antara kesombongan dan kerendahan hati, niat yang baik dan godaan, kebahagiaan dan kesedihan. Berdasarkan hal tersebut remaja menjadi bingung untuk memutuskan setiap tindakan yang akan diambilnya. Hal ini disebabkan oleh adanya faktor eksternal dari luar diri remaja yaitu remaja harus siap dan mampu menyesuaikan diri dengan lingkungan di samping faktor internal yang terjadi pada remaja yaitu perubahan biologis, kognitif, dan sosioemosional (Santrock, 2007).

Kenakalan remaja dapat diartikan sebagai perilaku-perilaku yang menyimpang dari peraturan orangtua, sekolah atau normanorma masyarakat, agama hingga hukum, yang apabila penyimpangan tersebut dilakukan oleh orang dewasa disebut sebagai kejahatan (Sarwono, 2010). Jensen menyatakan kenakalankenakalan remaja meliputi kenakalan yang menimbulkan korban fisik, kenakalan yang menimbulkan korban materi, kenakalan sosial yang tidak menimbulkan korban pada pihak/orang lain atau kenakalan yang membahayakan diri, dan kenakalan yang melawan status (Sarwono, 2010). Kenakalan remaja terjadi 
pada laki-laki maupun perempuan, akan tetapi remaja laki-laki lebih banyak terlibat kenakalan remaja dibanding remaja perempuan (Rebellon, Manasse, Agnew, Gundy, \& Cohn, 2015). Berdasarkan data BPS terdapat 200 remaja yang terlibat tindak pidana dengan persentase $93,5 \%$ laki-laki dan $6,5 \%$ perempuan yang didominasi oleh remaja usia 17 tahun dengan persentase $38 \%$ (Badan Pusat Statistik, 2010).

Kenakalan remaja tidak hanya terjadi pada remaja umum, akan tetapi juga remaja pondok pesantren. Hal ini didukung oleh beberapa berita kenakalan remaja yang melibatkan remaja pondok pesantren pada tahun 2016 dan 2017, diantaranya pada halaman sindonews diberitakan seorang santri tewas akibat dikeroyok oleh 12 temannya di Pondok Pesantren Darul Ulum Jombang (Bagus, 2016). Berdasarkan detiknews terdapat santri yang meninggal dunia akibat dikeroyok oleh 16 temannya karena dituduh mencuri uang dan hardisk (Sudjarwo, 2016). Kemudian, pada CNN diberitakan terdapat dua santri pondok moderen yang berkelahi hingga salah satu meninggal dunia (Sinuko, 2017). Selain berita, adanya kenakalan remaja pondok pesantren juga didukung oleh beberapa penelitian sebelumnya, pada penelitian Rifa'I (2009) diketahui bentuk kenakalan remaja pondok pesantren meliputi membolos, merokok, kencan atau pacaran, menginap di luar asrama, mencuri arus listrik, dan minum-minuman keras. Selain itu pada penelitian Aminatuzzuhriyah (2010) kenakalan remaja pondok pesantren meliputi kabur dari pondok, merokok, berkelahi dengan teman, dan terlambat kembali ke pondok.

Kenakalan remaja menurut Gunarsa dan Gunarsa (2004) dipengaruhi oleh tiga faktor, yaitu faktor pribadi, keluarga, dan lingkungan sosial. Faktor pribadi dibagi menjadi dua yakni faktor pribadi yang melekat by given dan tidak 
dapat diubah seperti jenis kelamin, usia, dan urutan kelahiran, serta faktor pribadi yang didapatkan dari pengetahuan, pengalaman dan keterampilan sehingga dapat ditingkatkan yaitu kecerdasan emosi dan selfesteem. Sejalan dengan penelitian Pratiwi (2017), ditemukan adanya hubungan signifikan negatif antara self-esteem dengan kenakalan remaja. Kenakalan Remaja laki-laki berpotensi lebih besar untuk melakukan kenakalan remaja dibandingkan anak dengan (Puspitawati, perempuan Christopher et al, 2007). Fakta menunjukan bahwa angka tertinggi tindak kenakalan ada pada usia 15-19 tahun (Kartono, 2008). Hal ini menunjukan bahwa jenis kelamin dan umur berhubungan dengan tingkat kenakalan remaja.

Selain karakteristik remaja, faktor individu lain yang berpengaruh terhadap kenakalan remaja adalah self-esteem. Self- esteem merupakan penilaian atau persepsi diri yang dilakukan oleh seorang individu terhadap dirinya atas penghargaan, penerimaan, dan perlakuan orang lain terhadap dirinya (Coopersmith, 1967). Selfesteem memiliki banyak aspek dan berkembang dalam konteks pengembangan pengertian seseorang terhadap identitas diri. Self-esteem adalah gabungan nilai diri yang dirasakan seseorang, bagaimana seseorang merasakan dirinya layak atas kebahagiaan, kesehatan dan kesejahteraan, rasa hormat, persahabatan, cinta, prestasi, dan kesuksesan (Youngs, 1991).

Selain harga diri, Daradjat (1988) mengemukakan faktorfaktor yang mempengaruhi kenakalan remaja salah satunya yaitu faktor internal lain yang dimungkinkan mempengaruhi kenakalan remaja adalah self efficacy, seperti yang ditunjukan oleh Bandura (dalam Baron \& Byrne, 2003) bahwa tingkah laku pelanggaran seperti agresi fisik, agresi verbal, pencurian, curang, 
bohong, pengrusakan, kenakalan, penggunaan alkohol dan obat-obatan dapat berhubungan dengan self efficacy. Seorang remaja dalam memecahkan masalah dalam proses penyesuaian diri memerlukan suatu keyakinan terhadap kemampuan diri sendiri karena hal tersebut akan menentukan tindakan yang dilakukan dan hasil yang ditunjukkan.

Berbagai penjelasan di atas menggambarkan bahwa terdapat permasalahan kontradiktif mengenai kenakalan remaja serta rendahnya harga diri yang dimiliki remaja pondok pesantren jika dibandingkan remaja yang bersekolah di lingkungan umum, maka dari itu perlu adanya penelitian lebih lanjut untuk mengetahui pengaruh harga diri terhadap kenakalan remaja khususnya remaja laki-laki di pondok pesantren, yang dalam hal ini dilakukan di pondok pesantren $\mathrm{x}$ sebagai salah satu pondok yang memiliki permasalahn tersebut.

\section{METODE}

Jenis penelitian ini
menggunakan metode crossectional

Observasional Analityc Design, menjelaskan adanya hubungan antara variabel melalui pengujian hipotesa. Penelitian ini menggali tentang interaksi faktor kenakalan remaja di Pesantren yakni faktor self esteem dan self efficacy.

Populasi dalam penelitian adalah seluruh remaja atau mahasiswa di Universitas Nurul Jadid, dengan kriteria inklusi adalah mahasiswa tingkat pertama, usia 19-21 tahun. Teknik pengambilan sampel dalam penelitian ini menggunakan teknik purposive sampling, sampel penelitian sejumlah 120 remaja mahasiswa.

Metode

pengumpulan data dalam penelitian ini adalah dengan menggunakan kuesioner tertutup. Dalam penelitian ini peneliti memberikan kuesioner yang disusun dengan menyediakan pilihan jawaban, sehingga responden hanya memberikan tanda pada 
jawaban yang dipilih. Dalam penelitian ini peneliti menggunakan tiga kuesioner yaitu kuesioner pengukuran kenakalan remaja, self efficacy dan self esteem. Kenakalan remaja diukur menggunakan kuesioner Adoption Self Report Delinquency Scale (ASRDS) yang diadaptasi dari Carroll et al. (1996). Instrumen self- esteem menggunakan kuesioner yang diadaptasi dari Rosenberg (1965) dengan jumlah 10 pertanyaan dengan skala Likert (1=sangat tidak sesuai, $2=$ tidak sesuai, 3=sesuai, 4=sangat sesuai) dan memiliki Cronbach's Alpha 0,564 . skala self efficacy yang berdasar pada 3 aspek yang dikemukakan oleh Bandura yaitu level, generality, dan strength.

Teknik analisis data yang digunakan dalam penelitian ini adalah menggunakan uji korelasi spearman mengetahui untuk independen dan variabel independen dan dependen (Notoatmojo, 2012).

\section{HASIL PENELITIAN}

1. Variabel Independen Tabel 1 Distribusi data berdasarkan variabel independent

\begin{tabular}{lcc}
\hline $\begin{array}{c}\text { Variabel } \\
\text { independen }\end{array}$ & f & \% \\
\hline Self Efficacy & & \\
Rendah & 12 & 5,1 \\
Sedang & 60 & 25,3 \\
Tinggi & 165 & 69,6 \\
\hline Self Esteem & & \\
\hline Rendah & 6 & 2,5 \\
Sedang & 89 & 37,6 \\
Tinggi & 142 & 59,9 \\
\hline Total & 237 & 100 \\
\hline
\end{tabular}

Tabel 1 menunjukkan hasil ditsribusi data pada variabel independent. Dimana variabel self efficacy tinggi sebanyak 165 (69,6\%), sebaliknya self efficacy rendah sebanyak $12 \quad(5,1 \%)$. Kemudian pada variabel self esteem sebanyak 142 $(59,9 \%)$ memiliki self esteem tinggi dan sejumlah $6 \quad(2,5 \%)$ memiliki self esteem rendah. 
2. Variabel Dependen

Tabel 2 Distribusi data berdasarkan variabel dependent

\begin{tabular}{|c|c|c|}
\hline $\begin{array}{c}\text { Variabel } \\
\text { independen }\end{array}$ & f & $\%$ \\
\hline $\begin{array}{l}\text { Perilaku } \\
\text { Berisiko } \\
\text { /Kenakalan } \\
\text { Remaja }\end{array}$ & & \\
\hline $\begin{array}{l}\text { Tidak } \\
\text { Berisiko }\end{array}$ & 138 & 58,2 \\
\hline $\begin{array}{l}\text { Berisiko } \\
\text { Rendah }\end{array}$ & 68 & 28,7 \\
\hline $\begin{array}{l}\text { Berisiko } \\
\text { Sedang }\end{array}$ & 23 & 9,7 \\
\hline $\begin{array}{l}\text { Berisiko } \\
\text { Tinggi }\end{array}$ & 8 & 3,4 \\
\hline Total & 237 & 100 \\
\hline
\end{tabular}

Tabel 2 menunjukkan pengakuan responden tentang prilaku berisiko yang dilakukan. Sebagian besar responden masuk ke dalam kategori perilaku tidak berisiko sejumlah $138(58,2)$
3. Hubungan

Antar Variabel

Tabel 3 Self Efficacy dg Perilaku Berisiko

\begin{tabular}{|c|c|c|c|c|c|c|c|c|c|c|}
\hline $\mathbf{S}$ & \multicolumn{10}{|c|}{ Kenakalan Remaja } \\
\hline $\begin{array}{l}e l \\
f \\
E \\
f f \\
i c\end{array}$ & $\begin{array}{l}\mathrm{Ti} \\
1 \\
\mathrm{~B} \\
\text { sil }\end{array}$ & & $\begin{array}{l}\mathrm{B} \\
\mathrm{si} \\
\mathrm{R} \\
\mathrm{d}\end{array}$ & & $\begin{array}{l}\mathrm{Be} \\
\text { isi } \\
\mathrm{O} \\
\mathrm{Se} \\
\text { an }\end{array}$ & & $\begin{array}{l}\mathrm{B} \\
\text { is } \\
\mathrm{T} \\
\mathrm{g}\end{array}$ & & & \\
\hline $\begin{array}{l}a \\
c \\
y\end{array}$ & $f$ & $\%$ & $\mathrm{f}$ & $\%$ & \begin{tabular}{l|l}
$\mathrm{f}$ & \\
\end{tabular} & $\%$ & $\mathrm{f}$ & $\%$ & $\mathrm{~F}$ & $\%$ \\
\hline $\begin{array}{l}\mathrm{R} \\
\mathrm{e} \\
\mathrm{n} \\
\mathrm{d} \\
\mathrm{a} \\
\mathrm{h}\end{array}$ & 1 & 4 & 1 & $\begin{array}{l}0 \\
4\end{array}$ & 5 & $\begin{array}{l}2 \\
1 \\
1\end{array}$ & 5 & $\begin{array}{l}2 \\
1 \\
1\end{array}$ & $\begin{array}{l}1 \\
2\end{array}$ & 5 \\
\hline $\begin{array}{l}\mathrm{S} \\
\mathrm{e} \\
\mathrm{d} \\
\mathrm{a} \\
\mathrm{n} \\
\mathrm{g}\end{array}$ & $\begin{array}{l}2 \\
8\end{array}$ & $\begin{array}{l}1 \\
1 \\
8\end{array}$ & $\begin{array}{l}2 \\
0\end{array}$ & $\begin{array}{l}8 \\
4\end{array}$ & 9 & $\begin{array}{l}3 \\
8 \\
8\end{array}$ & 3 & $\begin{array}{l}1 \\
3\end{array}$ & $\begin{array}{l}6 \\
0\end{array}$ & $\begin{array}{l}2 \\
5 \\
3\end{array}$ \\
\hline $\begin{array}{l}\mathrm{Ti} \\
\mathrm{n} \\
\mathrm{g} \\
\mathrm{gi}\end{array}$ & $\begin{array}{l}1 \\
0 \\
9\end{array}$ & $\begin{array}{l}4 \\
6\end{array}$ & $\begin{array}{l}4 \\
7\end{array}$ & $\begin{array}{l}1 \\
9 \\
8 \\
8\end{array}$ & 9 & $\begin{array}{l}3 \\
8 \\
8\end{array}$ & 0 & 0 & $\begin{array}{l}1 \\
6 \\
5\end{array}$ & $\begin{array}{l}6 \\
9 \\
6 \\
6\end{array}$ \\
\hline $\begin{array}{l}\text { T } \\
\text { ot } \\
\text { al }\end{array}$ & $\begin{array}{l}1 \\
3 \\
8\end{array}$ & $\begin{array}{l}5 \\
8\end{array}$ & $\begin{array}{l}6 \\
8\end{array}$ & $\begin{array}{l}2 \\
8 \\
6 \\
\end{array}$ & $\begin{array}{l}2 \\
3\end{array}$ & $\begin{array}{l}9 \\
7\end{array}$ & 8 & 3 & $\begin{array}{l}2 \\
3 \\
7\end{array}$ & $\begin{array}{l}1 \\
0 \\
0\end{array}$ \\
\hline
\end{tabular}

Tabel 3 menunjukkan bahwa mayoritas responden dengan self efficacy yang tinggi tidak melakukan perilaku berisiko sebanyak 109 (46\%). Hasil uji analisis statistik self efficacy dengan perilaku berisiko berdasarkan uji Spearman rho dengan nilai 
signifikansi $\mathrm{p}=0,000$ dan nilai $r=-0,334$. Nilai $p$ lebih kecil dari 0,05 menandakan $\mathrm{H} 1$ diterima dan HO ditolak, artinya terdapat hubungan antara self efficacy dengan perilaku berisiko atau kenakalan remaja, ni lai $\mathrm{r}$ menunjukkan semakin besar self efficay, semakin kecil nilai perilaku berisiko pada remaja.

4. Self esteem dengan Perilaku Berisiko

Tabel 4 self esteem dengan kenakalan remaja/perilaku

berisiko

\begin{tabular}{|c|c|c|c|c|c|c|c|c|c|c|}
\hline $\mathbf{S}$ & \multicolumn{10}{|c|}{ Kenakalan Remaja } \\
\hline $\begin{array}{l}e \\
l f \\
E \\
s \\
t\end{array}$ & $\begin{array}{l}\mathrm{Tic} \\
\mathrm{k} \\
\mathrm{Be} \\
\text { sik }\end{array}$ & & $\begin{array}{l}\mathrm{Be} \\
\mathrm{si} \\
\mathrm{Re} \\
\mathrm{dc}\end{array}$ & & $\begin{array}{l}\mathrm{Be} \\
\text { sil } \\
\mathrm{Se} \\
\text { ar }\end{array}$ & & $\begin{array}{l}\mathrm{Be} \\
\text { isi } \\
\mathrm{O} \\
\mathrm{Ti} \\
\mathrm{gg}\end{array}$ & & & \\
\hline $\begin{array}{l}\boldsymbol{e} \\
\boldsymbol{e} \\
\boldsymbol{m}\end{array}$ & $\mathrm{f}$ & $\%$ & $\mathrm{f}$ & $\%$ & $\mathrm{f}$ & $\%$ & $\mathrm{f}$ & $\%$ & $\mathrm{f}$ & $\%$ \\
\hline $\begin{array}{l}\mathrm{R} \\
\mathrm{e} \\
\mathrm{n} \\
\mathrm{d} \\
\mathrm{a} \\
\mathrm{h} \\
\end{array}$ & 0 & 0 & 1 & $\begin{array}{l}0 \\
4\end{array}$ & 2 & $\begin{array}{l}0 \\
8\end{array}$ & 3 & $\begin{array}{l}1 \\
3\end{array}$ & 6 & $\begin{array}{l}2 \\
5\end{array}$ \\
\hline $\begin{array}{l}\mathrm{S} \\
\mathrm{e} \\
\mathrm{d} \\
\mathrm{a} \\
\mathrm{n} \\
\mathrm{g}\end{array}$ & $\begin{array}{l}4 \\
2\end{array}$ & $\begin{array}{l}1 \\
7 \\
7 \\
7\end{array}$ & $\begin{array}{l}2 \\
9\end{array}$ & $\begin{array}{l}1 \\
2 \\
2\end{array}$ & $\begin{array}{l}1 \\
4\end{array}$ & $\begin{array}{l}5 \\
9\end{array}$ & 4 & $\begin{array}{l}1 \\
6 \\
7\end{array}$ & $\begin{array}{l}8 \\
9\end{array}$ & $\begin{array}{l}3 \\
7 \\
5 \\
5\end{array}$ \\
\hline $\begin{array}{l}\text { T } \\
\mathrm{i} \\
\mathrm{n} \\
\mathrm{g} \\
\mathrm{gi}\end{array}$ & $\begin{array}{l}9 \\
6\end{array}$ & $\begin{array}{l}4 \\
0 \\
5\end{array}$ & $\begin{array}{l}3 \\
8\end{array}$ & $\begin{array}{l}1 \\
6 \\
1 \\
1\end{array}$ & 7 & 0 & 1 & $\begin{array}{l}0 \\
4\end{array}$ & $\begin{array}{l}1 \\
4 \\
2\end{array}$ & $\begin{array}{l}6 \\
0\end{array}$ \\
\hline
\end{tabular}

\begin{tabular}{|l|l|l|l|l|l|l|l|l|l|l|}
\hline $\mathrm{T}$ & 1 & 5 & 6 & 2 & 2 & 9 & 8 & 3 & 2 & 1 \\
$\mathrm{o}$ & 3 & 8 & 8 & 8 & 3 &, & &, & 3 & 0 \\
$\mathrm{t}$ & 8 &, & &, & & 7 & & 4 & 7 & 0 \\
$\mathrm{a}$ & & 2 & & 7 & & & & & & \\
1 & & \multicolumn{1}{c|}{$\mathrm{P}=0,000, \mathrm{r}=-0,297$} \\
\hline \multicolumn{1}{|c|}{}
\end{tabular}

Tabel 4 menunjukkan bahwa mayoritas responden dengan self esteem yang tinggi tidak melakukan perilaku berisiko sebanyak 96 (40,5\%). Hasil uji analisis statistik self esteem dengan perilaku berisiko berdasarkan uji Spearman rho dengan nilai signifikansi $p=0,000$ dan nilai $r=-0,297$. Nilai $p$ lebih kecil dari 0,05 menandakan $\mathrm{H} 1$ diterima dan HO ditolak, artinya terdapat hubungan antara self esteem dengan perilaku berisiko remaja. Nilai $r$ atau arah korelasi bernilai negatif, dimana menandakan berlawanan arah. Artinya, semakin rendah nilai self esteem maka semakin tinggi nilai perilaku berisiko remaja 


\section{PEMBAHASAN}

Berdasarkan hasil uji hipotesis menunjukan hipotesis yang menyatakan

adanyahubungan self efficacy dan self esteem secara bersama-sama memberikan kontribusi yang signifikan terhadap kenakalan $r$, diterima. Hasil analisis dengan menggunakan teknik analisis regresi ganda diperoleh $\mathrm{p}$ - value 0,001 yang < dari 0,05 dan $\mathrm{F}$ hitung sebesar 7,664 nilai $\mathrm{F}$ tersebut $>$ dari $\mathrm{F}$ tabel sebesar 3,06. Hasil tersebut berarti self efficacy dan regulasi emosi dapat digunakan sebagai prediktor untuk memprediksi kenakalan remaja, semakin tinggi self efficacy dan regulasi emosi yang dimiliki siswa, maka semakin rendah kenakalan remaja.

Sebaliknya semakin rendah self efficacy dan regulasi emosi siswa maka semakin tinggi kenakalan remaja.

Sejalan dengan penelitian ( Anggai, 2015) menunjukkan Sumbangan efektif efikasi diri dengan perilaku berisiko terhadap ke- sehatan $9,1 \%$ di tunjukan oleh koe- fisien determinan ( r2 ) =0,091. Ber- arti masih terdapat $90,9 \%$ variabel la- in yang mempengaruhi perilaku berisiko terhadap kesehatan pada remaja.

Hasil penelitian ini menunjukkan bahwa efikasi dengan segala aspek yang terkandung didalamnya memang memberikan pengaruh terhadap perilaku berisiko terhadap kesehatan pada remaja. Sesuai dengan hasil peneli- tian, efikasi diri berhubungan negatif dengan perilaku berisiko terhadap ke- sehatan pada remaja, yaitu semakin tinggi efikasi diri maka semakin ren- dah perilaku berisiko terhadap kesehatan.

Self efficacy mampu membuat individu tersebut menguasai situasi sehingga mampu menghasilkan sesuatu yang positif (Santrock, 2003). Self efficacy yang tinggi pada remaja membuat mereka mampu mengatasi keadaan sulit yang sedang dihadapi sehingga menghasilkan sesatu yang positif dan dapat diterima oleh lingkungan sekitar, 
dengan hal tersebut remaja mampu terhindar dari kenakalan. Upaya peningkatan self efficacy dapat dilakukan dengan memperhatikan hal-hal yang mempengaruhinya, menurut Bandura (dalam Yufita, 1997) hal-hal yang mempengaruhi self efficacy antara lain dengan memberikan reward kepada remaja karena penguasaan tugas, memberikan informasi diri yang positif tentang kemampuan yang mereka miliki dan peran remaja dalam kelompoknya. Sejalan dengan penelitian (Khumairah \& Anriani, 2018) berdasarkan hasil analisis data, diketahui harga diri dan religisuitas secara signifikan berpengaruh negatif terhadap kenakalan remaja laki-laki di Pondok Pesantren Q. dengan nilai $F$ sebesar 246,967 dan signifikansi sebesar 0,000 serta presentase pengaruh mencapai 75,9\%. Kontribusi harga diri sebesar -0,312 dengan kesimpulan bahwa harga diri berpengaruh secara negatif signifikan terhadap kenakalan remaja laki-laki di Pondok Pesantren.

Temuan ini sejalan dengan penelitian Rosenberg, Rosenberg, dan McCord (1978); Donnellan et al. (2005); Caldwell et al. (2006) yang menyatakan bahwa semakin tinggi self-esteem remaja maka kenakalan remaja semakin rendah. Pendapat lain dikemukakan oleh Christopher et al. (2007) dan Cheng (2014) yang menyatakan bahwa selfesteem memiliki pengaruh terhadap kenakalan remaja, akan tetapi tidak memiliki hubungan linear dengan kenakalan remaja melainkan memiliki hubungan curvilinier atau bentuk U. Artinya, pada remaja dengan nilai selfesteem rendah maka selfesteem memiliki hubungan negatif dengan kenakalan remaja. Sementara itu, pada remaja dengan kategori self-esteem tinggi maka self-esteem memiliki hubungan positif dengan kenakalan remaja. Pada penelitian ini, self-esteem dan kenakalan remaja memiliki hubungan linear yang negatif signifikan 
karena sebaran selfesteem andikpas remaja pada penelitian ini mayoritas berada kategori rendah dan sedang.

Teori Kaplan dalam Rosenberg, Rosenberg, dan McCord (1978) menjelaskan bahwa selfesteem memiliki peranan yang penting terhadap tingkat kenakalan. Remaja yang memiliki kerusakan self-esteem akan mencari cara untuk memperbaiki self-respect dengan melibatkan dirinya dengan kelompok yang menyimpang yang memiliki komitmen untuk ditolak seluruh masyarakat. Selanjutnya, Rosenberg, Rosenberg, dan McCord (1978) menyatakan bahwa terdapat pandangan lain tentang hubungan selfesteem dan kenakalan yang lebih menekankan pada reaksi sosial terhadap penyimpangan. Apapun penyebab awal kenakalan, kecaman masyarakat terhadap tingkat kenakalan dan internalisasi dari sikap orang lain terhadap individu yang melakukan kenakalan arahnya akan menyebabkan harga diri yang rendah. Akan tetapi dalam penelitian Rosenberg, Rosenberg, dan McCord (1978) ditemukan bahwa pembuktian lebih mengarah pada spekulasi Teori Kaplan, untuk keseluruhan contoh penelitian, dan ketika dipisahkan antar status ekonomi, hasil uji regresi menunjukan bahwa pengaruh self-esteem terhadap kenakalan lebih besar dari pada pengaruh kenakalan terhadap selfesteem, terutama pada ekonomi menengah ke bawah dimana dukungan sosial lebih besar daripada tuntutan atau kecaman sosial.

Self Esteem/Harga diri yang positif biasanya akan menunjukkan pandangan yang positif tentang dirinya, dan puas akan kemampuan dirinya dan selalu memberikan penghargaan kepada dirinya sendiri. Coopersmith (dalam Trisakti dan Aastuti, 2014) menambahkan bahwa individu dengan harga diri positif cenderung percaya bahwa dirinya mampu, berarti, berharga, adanya penerimaan, kepedulian, 
dan rasa kasih sayang yang diterima dari individu yang lain.

Sebaliknya individu dengan harga diri negatif sering merasa bahwa dirinya tidak berharga, cenderung pasif dan sering menutu diri dalam lingkungan sosialnya. Widodo dan Pratitis (2013) individu dengan harga diri yang negatif adalah individu yang hilang kepercayaan diri dan tidak mampu menilai kemampuan dirinya sendiri.

$\begin{array}{lr}\text { Harga } & \text { diri } \\ \text { merupakan salah } & \text { satu } \\ \text { faktor internal yang }\end{array}$ mempengaruhi penyesuai sosial. Harga diri dapat meningkatkan

keberhasilan remaja untuk keyakinan diri dan memiliki peran penting saat berinteraksi seerta menyesuaikan diri dengan sosial. Penyesuaian sosial adalah proses mental dan tingkah laku yang mendorong seseorang untuk menyesuaikan diri dengan keinginan yang berasal dari dalam diri sendiri yang dspat diterima oleh lingkungannya. Mohammadi, Ghasemi,
Jafari dan Rad (2014) bahwa penyesuaian sosial adalah kecenderungan individu untuk merubah suatu perilaku atau tingkah laku agar sejalan dengan lingkungan, yang mana dalam suatu lingkungan atau kelompok mempunyai kriteria tertentu agar individu dapat diterima dalam lingkungan atau kelompok tersebut.

Faktor

mempengaruhi

penyesuaian sosial

menurut Maslihah (2011) adalah, faktor psikologis, kondisi fisik, perkembangan dan kematangaan, kondisi lingkungan. Hal ini menunjukan bahwa harga diri dengan segala aspek yang

didalamnya cukup memberikan sumbangan terhadap penyesuaian sosial meskipun penyesuaian sosial tidak hanya dipengaruhi oleh variabel harga diri. 
Daftar Pustaka

Maslihah, S. (2011). Studi Tentang Hubungan Dukungan Sosial, Penyesuaian Sosial Di Lingkungan Sekolah Dan Prestasi Akademik Siswa Smpit.

Mohammadi, E., Ghasemi, M. A., Jafari, M. R., \& Rad, M. R. (2014). Evaluation the Relation between Self-Esteem and Social Adjustment Dimensions in High school Female Students of Iran (Case Study: Isfahan, 2013-14 Academic Years). International Journal of Academic Research in Psychology, July, Vol. 1, No. 2, 42-48.

Khumairoh. R \& Anriani. F. 2018. Pengaruh Harga Diri dan Religisusitas Terhadap Kenakalan Remaja Laki-Laki di Pondok Pesantren Q. Jurnal Psikologi Pendidikan dan Perkembangan. Vol. 7, pp. 29-39.

Assyfa Boarding School Subang Jawa Barat. Jurnal Psikologi Undip
Vol. 10, No.2, Oktober, 103-114.

Widodo, A. S., \& Pratitis, N. T. (2013). Harga Diri Dan Interaksi Sosial Ditinjau Dari Status Sosial Ekonomi Orang Tua. Jurnal Psikologi Indonesia Mei, Vol. 2, No. 2, 131-138.

Trisakti, \& Astuti, K. (2014). Hubungan Antara Harga Diri Dan Persepsi Pola Asuh Orang Tua Yang Authoritatif Dengan Sikap Remaja Terhadap Penyalahgunaan

Narkoba. Jurnal Ilmiah Guru, No. 02/Tahun XVIII/November, 2431.

Pratiwi, I., \& Hastuti, D. 2017. Kenakalan Pada Remaja Anak Didik Lapas : Pengaruh Komunikasi orang Tua danSelf Esteem. Jur. Ilm. Kel. \& Kons., Januari 2017, p : 36-46.

Kartono, K. (2008). Patologi sosial 2: kanakalan remaja. Jakarta, ID: Raja Grafindo Persada.

Coopersmith, S. (1967). The antecendents of selfesteem. San Fransisco, US: W. H. Freeman and 
Company , T. B., Sarah, J.G., Kristy, K.A., \& Jessica, D. P. (2007). The relations among narcissism, self-esteem, and delinquency in a sample of at-risk adolescents. Journal of Adolescence, 30, 933942.

doi:10.1016/j.adolescen ce.2006.12.003.

Gunarsa, S., \& Gunarsa, Y. (2004). Psikologi praktis: anak, remaja dan keluarga. Jakarta, ID: BPK Gunung Mulia.

Youngs, B. B. (1991). How to develop self- esteem in your child : 6 vital ingredients. New York, US: Ballantine Books.

Rosenberg, M. (1965). Society and the adolescent self-image. Princeton, NJ: Princeton University Press.

Rosenberg, F. R., Rosenberg, M., \& McCord, J. (1978). Self-esteem and delinquency. Journal of Youth and Adolescence, 7(3), 279-294.

Puspitawati, H. (2006). Pengaruh faktor keluarga, lingkungan teman dan sekolah lanjut tingkat atas di Kota Bogor (Disertasi). Institut Pertanian Bogor, Bogor, Indonesia. 